УДК 699.8;691.175

O.C. Молодід, ORCID ID: 0000-0001-8781-6579, канд. техн. наук, доцент, Київський національний університет будівництва і архітектури, м. Київ

I.B. Резніченко, інженер

\title{
ЕКСПЕРИМЕНТАЛЬНІ ДОСЛІДЖЕННЯ ТЕХНОЛОГІЇ ГЕРМЕТИЗАЦЇ̈ СТИКІВ МАТЕРІАЛАМИ ПОЛІУРЕТАНОВИМИ SPT RESINS
}

\begin{abstract}
Анотація. Наведені результати досліджень технологї герметизацї стиків між збірними залізобетонними конструкціями за допомогою нагнітання в порожнини поліуретанового матеріалу SPT Resins. Для виконання експериментальних досліджень було запроектовано та створено спеціальний стенд за допомогою якого створювалися умови близькі до реальних. Основна задача досліджень полягала у підготовщі нижньої частини стиків до початку ін'єктування поліуретанового матеріалу для попередження його витікання. Для цього нижні частини швів між перетинками були завчасно запо-

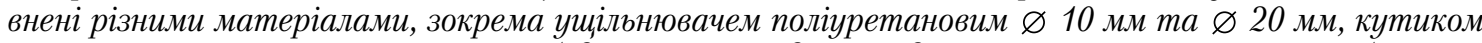
металевим 25x25x3, L=1010, клеєм будівельним швидкотверднучим (на основі цементу) або піною монтажною. В результаті досліджень встановлено, що при правильній підготовці нижніх частин стиків при нагнітанні в порожнини поліуретанового матеріалу SPT Resins, можна досягти хорошого результату, а саме заповнити порожнини на 95 - $99 \%$.
\end{abstract}

Ключові слова: герметизація, стик, шов, поліуретан, підготовка шва, технологія.

Постановка проблеми.

Комунальні та приватні підприємства, що займаються експлуатацією і обслуговуванням підземних переходів, каналізаційних колекторів, тунелів метро та інших будівель і споруд зі збірного залізобетону постійно стикаються з проблемою розгерметизації стиків між окремими елементами таких конструкцій. Поширеною проблемою підземних переходів є втрата функціональних властивостей зовнішньої гідроізоляції в результаті чого через стики між плитами покриття протікає вода та пошкоджує внутрішнє опорядження. Подібна проблема спостерігається і в тунелях метро, коли через щілини або тріщини в огороджувальних конструкціях протікає вода з вимиванням грунтів в середину тунелю. При розгерметизації стиків між залізобетонними кільцями колекторів спостерігається зворотна ситуація коли каналізаційні стоки через стики потрапляють у грунт та підземні води.

Отже, зазначена проблема є актуальною та потребує наукового підходу для її вирішення.
Аналіз останніх джерел. При новому будівництві підземних споруд нормативними документами на їх проектування, зазвичай, передбачається влаштування зовнішньої гідроізоляції та герметизація стиків між збірними елементами. Зокрема для тунелів метрополітену передбачається зовнішня обклеювальна гідроізоляція та пружні компенсатори в деформаційних швах [1]. Каналізаційні тунелі слід захищати від інфільтрації поверхневих і грунтових вод, а також ексфільтрації стічних вод. Водонепроникність облицювань потрібно забезпечувати застосуванням відповідних матеріалів, обклеюванням облицювань гідроізоляційними матеріалами, влаштуванням металоізоляції, ущільненням прилеглого до тунелю грунтового масиву цементацією, глинізацією, силікатизацією або іншими методами, нагнітанням за облицювання спеціальних розчинів, закладенням швів i отворів із зачеканенням швидкотужавними матеріалами або пневмобетоном [2]. Сучасний будівельний ринок пропонує широкий вибір матеріалів та технологій влаштування нової гідроізоляції при зведенні

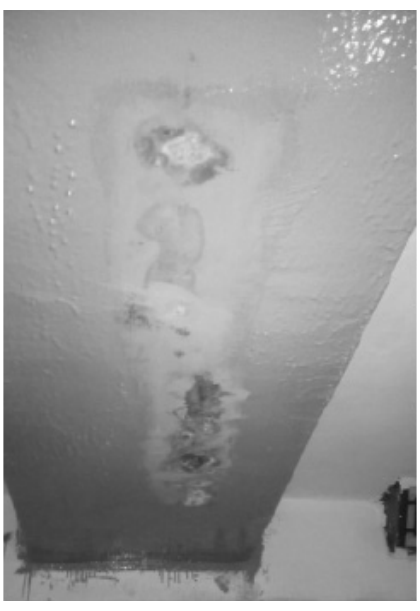

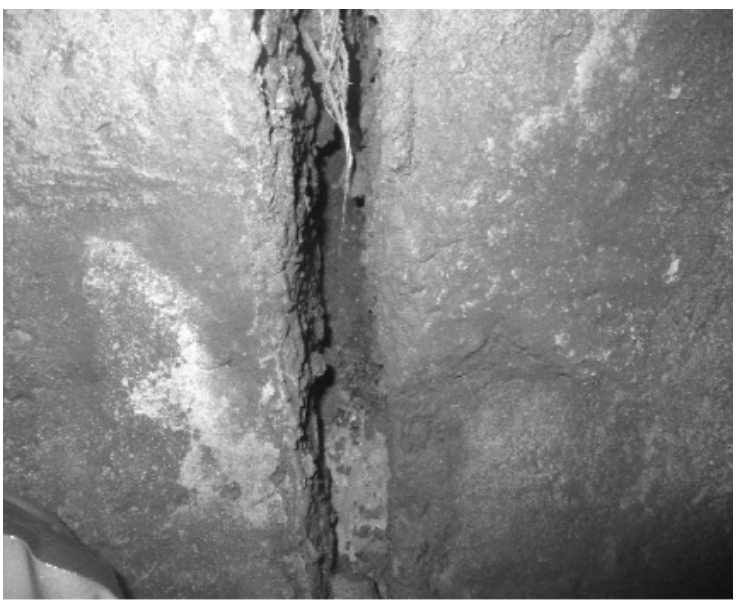

6

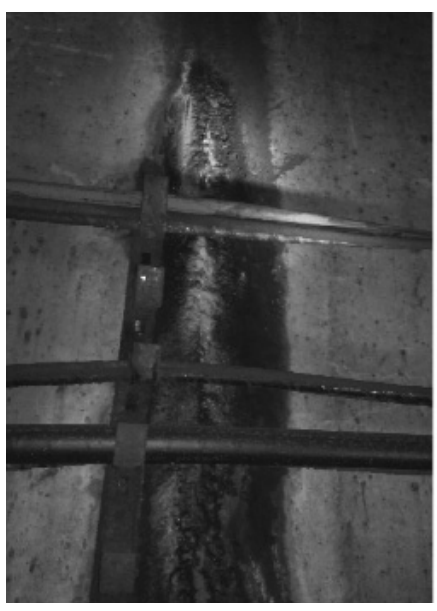

Рис. 1. Фото протікань води через розгерметизовані стики: а - підземний перехід; б - каналізаційний колектор; в - тунель метро 
будівель і споруд. Проте, конструктивно-технологічні рішення з відновлення стиків між збірними елементами які були б рекомендовані нормативною або науково-технічною літературою фактично відсутні. Існуючі рішення 3 відновлення стиків призначені для герметизації конструкцій панельних житлових та промислових будівель [3], деформаційних швів у протифільтраційних облицюваннях каналів і водоємів [4], ремонту тріщин [5]. Технології, які можна було б використовувати при герметизації стиків зазначених раніше споруд, занадто трудомісткі, тривалісні та виконуються з пошкодженням конструкцій, що є неприпустимим [6]. Тому, дослідження технології герметизації стиків між залізобетонними елементами матеріалами поліуретановими SPT Resins є метою даної статті.

Результати досліджень. Експериментальні дослідження технології герметизації стиків між залізобетонними елементами 3 використання матеріалів поліуретанових SPT Resins проводили у спеціально обладнаній лабораторії, в умовах близьких до натурних.

В якості залізобетонних елементів, між якими герметизували стики, використовували залізобетонні перетинки марки 1 ПБ 10-1.

Для виконання експериментальних досліджень було запроектовано та створено спеціальний стенд 3 опалубних конструкцій (рис. 2, 3).
При створенні стенду було використано наступне обладнання: опалубка; залізобетонні перетинки марки 1 ПБ 10-1; пісок дрібнозернистий; поліетиленова плівка; вода; ущільнювач поліуретановий $\varnothing 10$, та $\varnothing 20$; кутик металевий № 6, L=1010; клей будівельний; піна монтажна.

Стенд складався 3 опалубних телескопічних металевих стійок на які монтували дерев'яні головні та другорядні балки. На поверхню другорядних балок вкладали суцільний лист фанери в якому завчасно вирізали отвори шириною 30 мм та довжиною 950 мм (в місцях вказаних на рис. 3). Вздовж отворів попарно вкладали залізобетонні балки так, щоб грані балок, з розмірами 1030 мм х 65 мм, лягали на фанеру. При цьому, проміжок між балками залишався рівним по всій довжині та висоті балок і становив 10 мм і імітував стик між двома залізобетонними елементами. Далі збирали короб із дерев'яних балок, які розташовувалися за межами вкладених перетинок та слугували обмежувачами для всипаного піщаного грунту. Посередині стенду вертикально встановлювали лист фанери, який виконував функцію перетинки між сухим та мокрим грунтом.

По зовнішньому периметру балочки фіксували металевими кутиками, щоб виключити їх зміщення під час розширення полімеру.

Експериментальний стенд запроектовано таким чином, щоб можна було дослідити технологію герме-

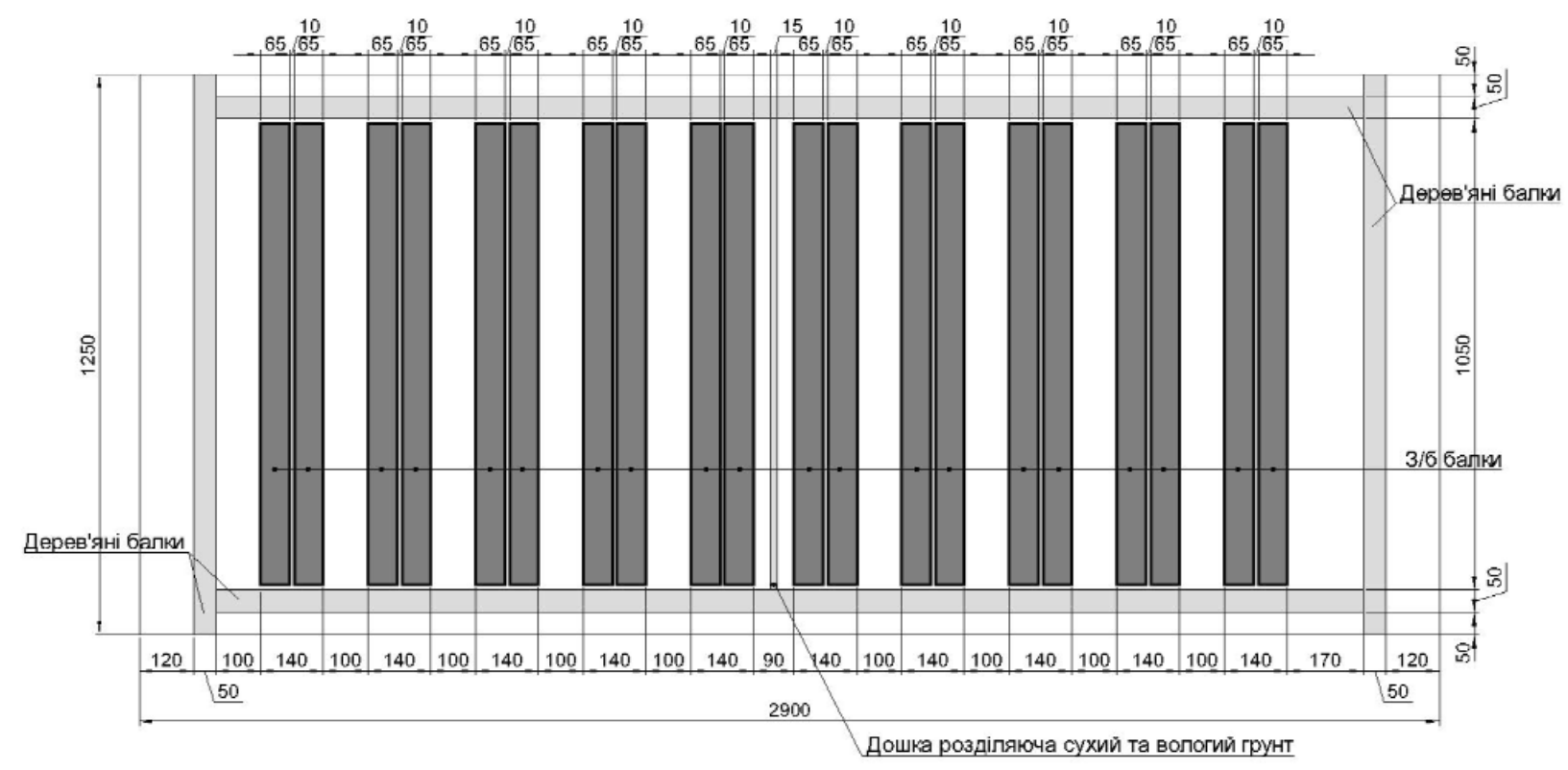

Рис. 2. Схема експериментального стенду

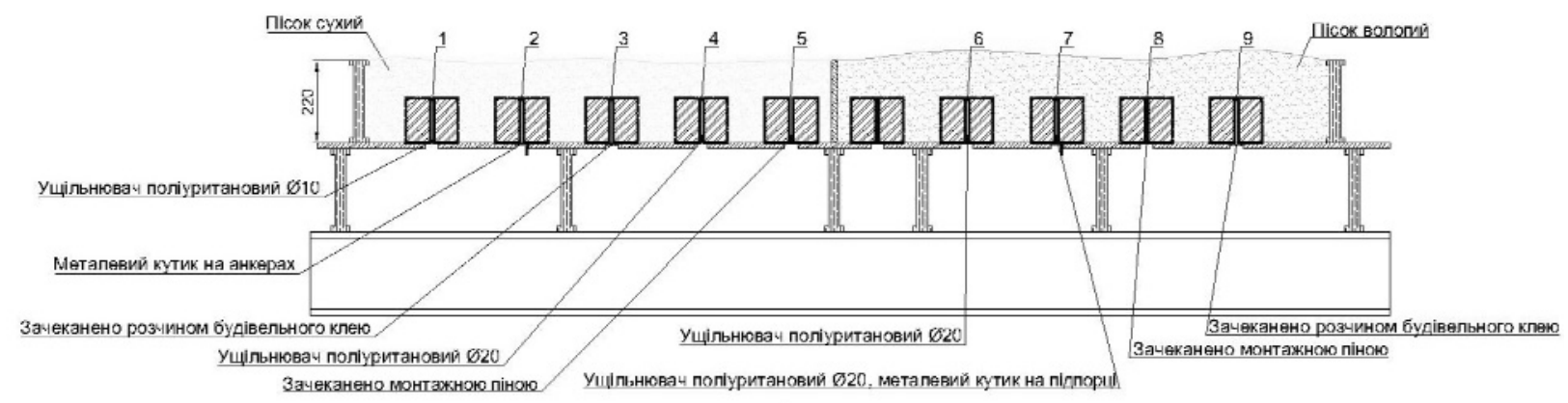

Рис. 3. Експериментальний стенд. Розріз 
тизації стиків між сухим та мокрими залізобетонними елементами. Для цього половину стенду було вкрито поліетиленовою плівкою та прорізано в ній отвори в місцях "стиків" між конструкціями. Після цього конструкції було засипано піском на висоту 220 мм. За 30 хв до початку експериментальних досліджень у частину стенду, дно якої було вкрито поліетиленовою плівкою, рівномірно вилили 40 л води.

Безпосередньо перед початком експериментальних досліджень 3 нагнітання матеріалу SPT Resins в стики, поверхню грунту накривали суцільним листом фанери та встановлювали на нього вантаж масою 350 кг. Таку дію виконували для того, щоб під час розширення, поліуретановий матеріал не вийшов на поверхню та не піднімав верхній, легкий, шар грунту.

Основна задача дослідження технології герметизації стиків полягала у підготовці їхньої нижньої частини до початку ін'єктування поліуретанового матеріалу. Для цього нижні частини швів між перетинками були завчасно заповнені різними матеріалами, зокрема ущільнювачем поліуретановим $\varnothing 10$ мм та $\varnothing 20$ мм, кутиком металевим 25x25x3, L=1010, клеєм будівельним швидкотверднучим (на основі цементу) або піною монтажною (рис. 3).

Згідно плану проведення експерименту, стики між перетинками були пронумеровані № $1-9$. Стики № $1-5$ знаходилися в сухому стані, а стики № $6-9-$ у мокрому:

- стик № 1 - заповнено поліуретановим ущільнювачем - 10 мм;

- стик № 2 - закрито металевим кутиком на анкерах;
- стик № 3 - зачеканено розчином будівельного клею;

- стик № 4 - заповнено ущільнювачем поліуретановим $\varnothing 20$ мм;

- стик № 5- заповнено монтажною піною, залишки піни були завчасно обрізані;

- стик № 6 - заповнено ущільнювачем поліуретановим $\varnothing 20$ мм;

- стик № 7 - заповнено ущільнювачем поліуретановим $\varnothing 20$ мм та закрито металевим кутиком, який притиснутий підпіркою;

- стик № 8 - заповнено монтажною піною, залишки піни завчасно обрізані;

- стик № 9 - зачеканено розчином будівельного клею.

У стиках пробурювали по 2 наскрізні вертикальні отвори $\varnothing 12$ мм, що розміщувалися рівновіддалено між собою та від країв (330 мм). У створені отвори вкручували пластмасові ін'єктори зі зворотнім клапаном.

Перед початком ін'єктування поліуретановий матеріал SPT Resins був нагрітий до $+35^{\circ} \mathrm{C}$.

Матеріал ін'єктували шляхом під'єднання до ін'єктора спеціального пістолету, до якого, через гумові рукава, подається матеріал SPT Resins та стиснене повітря. Натисканням на гачок пістолета ін'єктований матеріал під тиском проходив у пластиковий ін'єктор.

Ін'єктування полімеру у шви між балками проводили почергово від № 1 до № 9. Враховуючи досвід ін'єктування стиків № 1 та № 4, перед ін'єктуванням стику № 7 було додано кутик на підпорці, для виклю-

Таблиця 1. Результати експериментальних досліджень технології герметизації стиків

\begin{tabular}{|c|c|c|c|c|c|c|}
\hline $\begin{array}{l}\text { № } \\
\text { дос } \\
\text { лід } \\
\text { у }\end{array}$ & $\begin{array}{l}\text { Час ін'єкту- } \\
\text { вання } \\
\text { матеріалу, } \\
\text { секунди }\end{array}$ & $\begin{array}{c}\text { Вид підготовки нижньої } \\
\text { частини стику між } \\
\text { перетинками }\end{array}$ & $\begin{array}{c}\text { Об'єм } \\
\text { витраченого } \\
\text { матеріалу, } \\
\text { см }^{3} \\
\end{array}$ & \begin{tabular}{|c|} 
Об'єм шва \\
між \\
пертинками, \\
см $^{3}$ \\
\end{tabular} & $\begin{array}{c}\text { Заповне } \\
\text { ність } \\
\text { шва, \% }\end{array}$ & \begin{tabular}{|c|} 
Показники \\
встановлені \\
за мету
\end{tabular} \\
\hline \multicolumn{7}{|c|}{ Дослідження з балочками, поверхня яких мала природню вологість } \\
\hline 1 & \multirow{5}{*}{5} & \begin{tabular}{|l|} 
ущільнювач \\
поліуретановий Ø 10
\end{tabular} & \multirow{5}{*}{62} & \multirow{5}{*}{123,6} & 93 & \multirow{5}{*}{$95-100 \%$} \\
\hline 2 & & $\begin{array}{lll}\begin{array}{l}\text { металевий } \\
\text { анкерах }\end{array} & \text { кутик } \\
\end{array}$ & & & 75 & \\
\hline 3 & & $\begin{array}{l}\text { розчин будівельного } \\
\text { клею }\end{array}$ & & & 80 & \\
\hline 4 & & $\begin{array}{l}\text { ущільнювач } \\
\text { поліуретановий } \underline{\varnothing} 20\end{array}$ & & & 90 & \\
\hline 5 & & монтажна піна & & & 99 & \\
\hline \multicolumn{7}{|c|}{ Дослідження з балочками, поверхня яких була мокрою } \\
\hline 6 & \multirow{4}{*}{5} & $\begin{array}{l}\text { ущільнювач } \\
\text { поліуретановий Ø } 20\end{array}$ & \multirow{4}{*}{62} & \multirow{4}{*}{123,6} & 85 & \multirow{4}{*}{$95-100 \%$} \\
\hline 7 & & $\begin{array}{l}\text { ущільнювач } \\
\text { поліуретановий } \underline{\varnothing} \quad 20, \\
\text { та металевий кутик на } \\
\text { підпорці }\end{array}$ & & & 93 & \\
\hline 8 & & монтажна піна & & & 95 & \\
\hline 9 & & $\begin{array}{l}\text { розчин будівельного } \\
\text { клею }\end{array}$ & & & 95 & \\
\hline
\end{tabular}



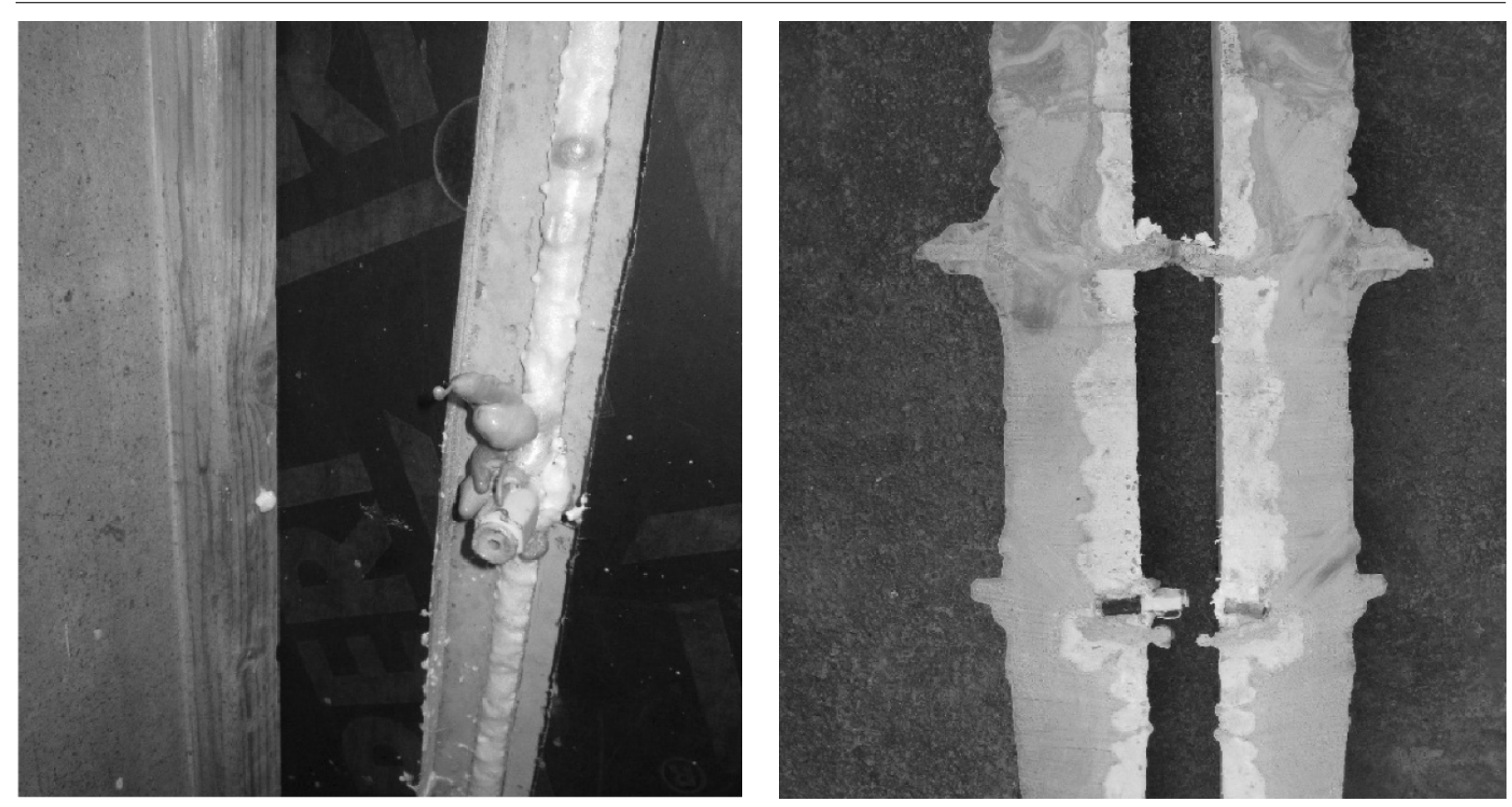

Рис. 4. Вигляд стику №5 нижня частина якого заповнена монтажною піною
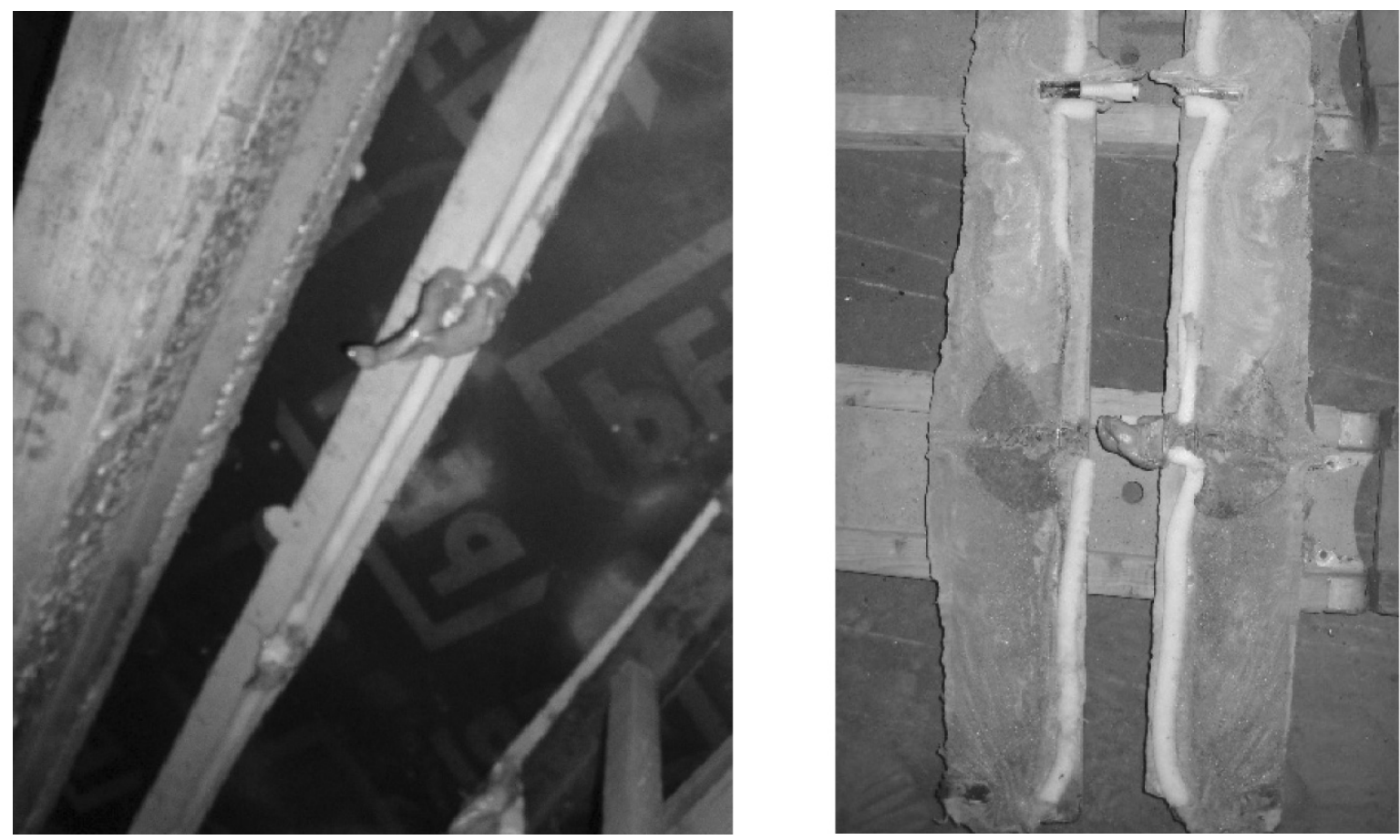

Рис. 5. Вигляд стику №6 нижня частина якого заповнена ущільнювачем поліуретановим $\varnothing 20$

чення видавлювання зі шва ущільнювача полімером при розширенні.

Після ін'єктування матеріалів поліуретанових SPT Resins в стики, було отримано загерметизовані шви між залізобетонними конструкціями. Незначна кількість матеріалу, під час його розширення, видавилася по краях та в місцях встановлення ін'єкторів.

На наступний день після проведення експериментів, піщаний грунт із короба стенду було видалено, а сам короб розібрано.

Після розбирання стенду всі зразки детально оглядали та виконали їх фотофіксацію. Для отримання даних про ступінь заповнення стиків між конструкціями полімерним матеріалом було виконано повздовжнє розрізування всіх зразків посередині за- герметизованих швів (в окремих місцях не вдалося виконати рівний розріз через високу щільність матеріалу, як наслідок, на окремих зразках матеріал SPT Resins присутній лише на одній з двох перетинок). Після розрізування стиків виконано аналіз щодо іхньої наповненості герметизаційним матерілом (табл. 1, рис. $4-6$ ).

Як результат встановлено, що поліуретановий матеріал однаково добре заповнив порожнини стиків як у грунті з природньою вологістю, так і у водонасиченому. Утворені в результаті експерименту загерметизовані шви дають можливість стверджувати, що рідкий поліуретановий матеріал в результаті термічної реакції збільшився в декілька разів (приблизно в 2 рази) та набрав високої міцності. 

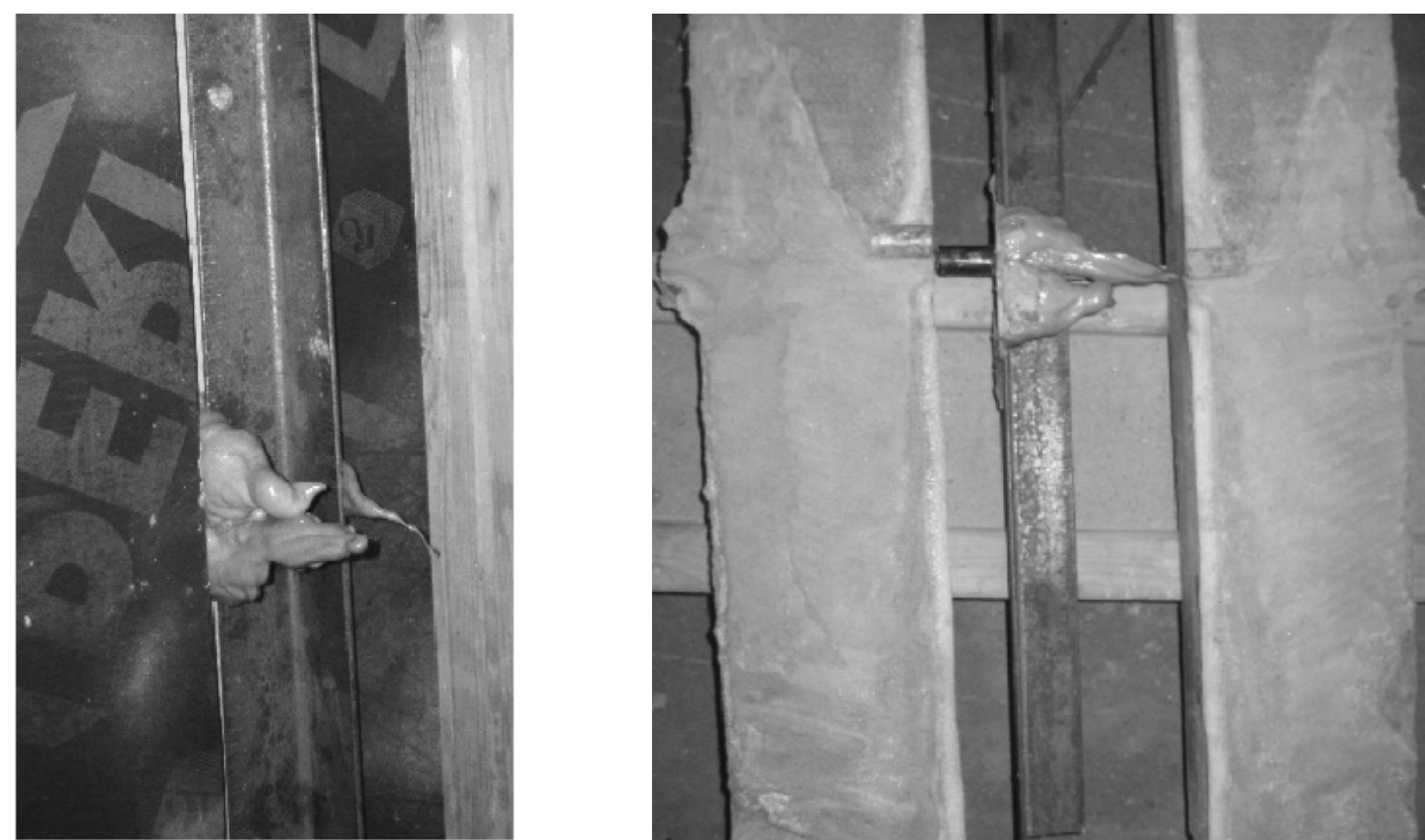

Рис. 6. Вигляд стику №7 нижня частина якого заповнена ущільнювачем поліуретановий $\varnothing 20$ з притисканням металевого кутика на підпорці

Візуальний огляд стиків між перетинками після ïx розпилювання дає можливість стверджувати, що порожнини заповнені поліуретановим матеріалом на $75-99 \%$ (табл. 1 ).

\section{Висновки.}

1.У результаті проведення ряду експериментальних досліджень технології герметизації стиків між збірними залізобетонними конструкціями за допомогою нагнітання в порожнини поліуретанового матеріалу SPT Resins встановлено, що при правильній підготовці нижніх частин стиків можна досягти хорошого результату, а саме заповнити порожнини поліуретановим матеріалом на $95-99 \%$.

2. Заповненості шва в $95-100 \%$ вдалося досягти при заповненні нижньої частини стиків монтажною піною та розчином будівельного клею.

3. Заповненості порожнини стиків в $90-95 \%$ вдалося досягти при заповненні нижньої частини стиків ущільнювачами поліуретановими.

\section{Jimepamypa}

1. Споруди транспорту. Метрополітени: ДБН В.2.3-7-2010. - [Чинний від 2011-10-01]. - К.: Мінрегіонбуд України, 2011. - 152 с. - (Національний стандарт України)

2. Каналізація. Зовнішні мережі та споруди. Основні положення проектування. Поправка: ДБН В.2.5-75:2013. [Чинний від 2014-01-01]. - К.: Мінрегіон України, 2013. - 219 с. - (Національний стандарт України)

3. Матеріал герметизуючий бутилрегенератний. Технічні умови: ДСТУ Б В.2.7-78-98 - [Чинний від 1999-01-01]. К.: Держбуд Украйни, 1999. - 31 с. - (Національний стандарт Украйни)

4. Способ комплексной герметизации межпанельных швов и стыков сборных бетонных облицовок мелиоративных каналов / С. С.Марченко, П. С. Попов, Д. П. Арьков, О. Г. Семененко. // Научно-агрономический журнал, "Федеральный научный центр агроэкологии, мелиоращии и защитного лесоразведения". - 2018. - C. 38-41.

5. Testing and assessment of epoxy injection crack repair for residential concrete stem walls and slabs-on-grade - Earthquake Engineering Richmond: NAHB Research Center, Inc. Upper Marlboro, 2002. - 32 p.

6. Опыт работ по гидроизоляции подземных сооружений / В. М.Дианов, А. В. Савич, К. С. Пашин, С. А. Графкин. // Санкт-Петербург: Записки Горного института. - 2012. - С. 145-150.

\section{References}

1. Transport facilities. Underground: DBN V.2.3-7-2010. - [Effective from 2011-10-01]. - Kyiv: Ministry of Regional Development of Ukraine, 2011. - 152 p. - (National Standard of Ukraine)

2. Sewage. Outdoor networks and facilities. The main provisions for the design. Amendment: DBN V.2.5-75 2013. - [Effective from 2014-01-01]. - Kyiv: Ministry of Regional Development of Ukraine, 2013. - 219 p. - (National Standard of Ukraine) 3. Butyl regenerated sealing material. Specifications: DSTU B V.2.7-78-98 - [Effective from 1999-01-01]. - Kyiv: State Committee of Ukraine for Construction and Architecture, 1999. - 31 p. - (National Standard of Ukraine)

4. The method of complex sealing of inter-panel seams and joints of precast concrete mantels for reclamation channels / S.S. Marchenko, P.S. Popov, D.P. Arkov, O.G. Semenenko. // Scientific and Agronomic Journal, Federal Research Center for Agroecology, Land Reclamation and Protective Afforestation. - 2018. - pp. 38-41.

5. Testing and assessment of epoxy injection crack repair for residential concrete stem walls and slabs-on-grade - Earthquake Engineering Richmond: NAHB Research Center, Inc. Upper Marlboro, 2002. - 32 p.

6. Experience in waterproofing underground structures / V.M. Dianov, A.V. Savich, K.S. Pashin, S.A. Grafkin. // St. Petersburg: Notes of the Mining Institute. - 2012. - pp. 145-150. 


\title{
А. С. Молодид
}

ORCID ID: 0000-0001-8781-6579, канд. техн. наук, доцент, Киевский национальный университет строительства и архитектуры., г. Киев

И. В. Резниченко, инженер

\section{ЭКСПЕРИМЕНТАЛЬНЫЕ ИССЛЕДОВАНИЯ ТЕХНОЛОГИИ ГЕРМЕТИЗАЦИИ СТЫКОВ МАТЕРИАЛАМИ ПОЛИУРЕТАНОВЫМИ SPT RESINS.}

\begin{abstract}
Аннотация. Приведенные результаты исследований технологии герметизации стыюков между сборными железобетонными конструкциями при заполнении в полости полиуретанового материала SPT Resins. Для выполнения экспериментальных исследований было запроектировано и создан специальный стенд с помощью которого создавались условия близки к реальным. Основная задача исследований заключалась в подготовке нижней части стыков до начала инъецирования полиуретанового материала для предупреждения его утечки. Для этого нижние части швов между перемыиками были заблаговременно заполнены различными материалами, в частности уплотнителем полиуретановым $\varnothing 10$ мм и 20 мм, уголком металлическим 25×25×3, $L=1010$, клеем строительным быстротвердеющий (на основе иемента) или пеной монтажной. В результате исследований установлено, что при правильной подготовке нижних частей стыков при нагнетании в полости полиуретаново20 материала SPT Resins, можно достичь хорошего результата, а именно заполнить полости на $95-99 \%$.
\end{abstract}

Ключевые слова: герметизация, стык, шов, полиуретан, подготовка шва, технология.

\section{A. S. Molodid}

ORCID ID: 0000-0001-8781-6579, Cand. tech Sciences, Associate Professor, Kyiv National University of Construction and Architecture., Kyiv

I.V. Reznichenko, engineer

\section{EXPERIMENTAL RESEARCH OF TECHNOLOGY OF HERMETIZING STYLES WITH MATERIALS OF POLYURETHANE SPT RESINS.}

Annotation. The hereinafter contained results of the research studying the technology of sealing joints between precast concrete structures when filling in cavities with SPT Resins polyurethane material. To carry out experimental research, a special stand was designed and assembled to create conditions close to the real ones. The main target of the research was to prepare the bottom of the joints prior to the injection of polyurethane material to prevent its leakage. To this end, the bottoms of the seams between membranes were filled with different materials in advance, in particular, the polyurethane sealing $\varnothing 10 \mathrm{~mm}$ and $\varnothing 20 \mathrm{~mm}$, metal L-steel $25 \times 25 \times 3, L=1010$, fast-hardening adhesive for building (cement based) or mounting foam. As a result of the research, it was found that with a due preparation of the lower parts of joints it is possible to achieve a good result, namely to fill the cavity by $95-99 \%$ when SPT Resins polyurethane material is pumped under pressure into the cavity.

Keywords: sealing, joint, seam, polyurethane, seam preparation, technology. 